\title{
Evaluation of cytotoxicity through MTS test of 2-ACBs (2-dDCB AND tDCB) after exposure to hepatic cells -
}

\section{Studies in vitro}

\author{
Barbezan $^{\mathrm{a}}$, A. B., Carvalho ${ }^{\mathrm{a}}$, L. R., Vieira ${ }^{\mathrm{a}}$, D. P., Machado-Santelli ${ }^{\mathrm{b}}$, G. M., \\ Martins $^{\text {a }}$, R., Villavicêncio ${ }^{\text {a }, ~ A . ~ L . ~ C . ~ H . ~}$
}

${ }^{a} I P E N-C N E N$ / SP (Nuclear and Energy Research Institute, National Nuclear Energy Commission), Department CTR, 03178-200, São Paulo, SP, Brazil

${ }^{b}$ Universidade de São Paulo, Department of Cell Biology and Development of the Institute of Biomedical Sciences, 03178-200, São Paulo, SP, Brazil

Author contact: abarbezan@ipen.br

\begin{abstract}
Food irradiation has been approved in more than 60 countries for many applications in a wide variety of foods. 2-Alkylcyclobutanones (2-ACBs) are the only known radiolytic products formed when foods containing fatty acids are irradiated. Despite the importance of food irradiation, the toxicological potential of 2-ACBs in irradiated food is still no fully understood. In this study we investigated the cytotoxic effects of irradiated palmitic and stearic fatty acids byproducts, 2-dDCB and 2-tDCB, in hepatic cell lines (HepG2, BRL3A and HTC). The cytotoxic effects of 2-dDCB and 2-tDCB were evaluated at 100, 300 and $500 \mu \mathrm{M}$ for 24 and 48 hours and the cell viability was measured using the MTS assay. While no toxicity was observed for 2-tDCB in all cells for all tested conditions, 2-dDCB was found to be toxic to BRL3A cells (at $100 \mu \mathrm{M}$ after 48 hours) and HTC cells (at 24 hours in all tested concentrations). HepG2 cells on the other hand, were found to be resistant to 2-dDCB-induced toxicity. Overall our data shows that the byproduct 2-tDCB is not toxic for hepatic cells while 2-dDCB can be used has a potential marker for food irradiation-induced toxicity.
\end{abstract}

Keywords: Food irradiation, Cytotoxicity, 2-Dodecyclobutanone, 2-Tetradecylcyclobutanone, 2-Alkylcyclobutanones 


\section{INTRODUCTION}

\subsection{Food Irradiation}

Food irradiation is usually performed with X-rays from an electron accelerator, accelerated electron beams, or with the gamma radiation generated by the radioactive isotopes Cobalt-60 and Cesium-137 $\left({ }^{60} \mathrm{Co}\right.$ or $\left.{ }^{137} \mathrm{Cs}\right)$ (Kim et al., 2004).

Depending on the absorbed dose of radiation, several effects can be achieved resulting in reduced storage losses, increased shelf life and improved food safety, reducing the biological load of pathogenic microorganisms possibly present in raw foods (Farkas et al., 2014). TAB. 1 presents the recommended doses of radiation used for food irradiation.

\subsection{2-Alkylcyclobutanones (2-ACBs)}

Alkylcyclobutanones (2-ACBs) are the only radiolytic products formed from irradiated foods containing triglycerides (fatty acids). 2-ACBs were first detected by Letellier and Nawar in 1972 in irradiated foods. At that time, it was found that when C6, C8, C10, C12, C14, C16, and C18containing triglycerides were irradiated, the 2-alkyl group of alkylcyclobutanones was usually replaced resulting in the formation of radiolytic products.

2-ACBs are cyclic compounds formed by the loss of an oxygen electron over the carbonyl of a fatty acid or triglyceride, followed by a rearrangement process to produce ionization resulting in the production of highly active free radicals. Palmitic acids, stearic, oleic, and linoleic are the primary fatty acids present in foods that, when subjected to irradiation process, are transformed into 2-dDCB (2-Dodecylcyclobutanone), 2-tDCB (2-Tetradecylcyclobutanone), 2 -tDeCB (2-tetradec-50enylcyclobutanone), and 2-tDecBB2-tetradec-5'8'-dienylcyclobutanone), respectively (Song et al., 2014; Gadgil et al., 2002) Figure 1. 
Table 1: Radiation doses applied in kGy in specific groups of foods according to the intended purpose. Source: Adapted from Ehlermann (2016).

\begin{tabular}{|c|c|}
\hline \multicolumn{2}{|l|}{ Low Doses (up to $1 \mathrm{kGy}$ ) } \\
\hline Inhibition of sprouting & Potato, onion, garlic, ginger root, chestnut \\
\hline Insect disinfestations & Cereals, pulses, fresh and dried fruits \\
\hline Parasitic disinfection & Fresh pork and fish \\
\hline Delay of ripening & Tropical fruits, seasonal fruits \\
\hline \multicolumn{2}{|l|}{ Medium Doses (1 - 10 kGy) } \\
\hline Extension of shelf-life & Fish and seafood, strawberries, asparagus \\
\hline $\begin{array}{l}\text { Inactivation of spoilage and pathogenic } \\
\text { bacteria }\end{array}$ & Chicken feet, raw milk cheese, life oysters, pet feed and treats \\
\hline Improving technological properties & $\begin{array}{l}\text { Reduced cooking time (dehydrated vegetables). } \\
\text { Removal off-flavour, accelerating ripening of wine and spirits }\end{array}$ \\
\hline \multicolumn{2}{|l|}{ High Doses (above 10 kGy) } \\
\hline Industrial sterilization & Meat, poultry, seafood, sausages, spacefood \\
\hline Combination with mild heat & Prepare meals, hospital diets \\
\hline Descontamination of additives/ingredients & Spices, enzime preparations, natural gum, gel \\
\hline
\end{tabular}


Figure 1: Formation of 2-ACB from a triglyceride after radiation.

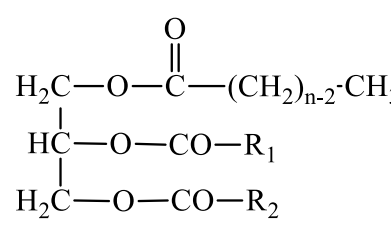

Triglyceride hv, $\mathrm{e}^{-}, \mathrm{RX}$

$\overrightarrow{\text { Irradiation }}$

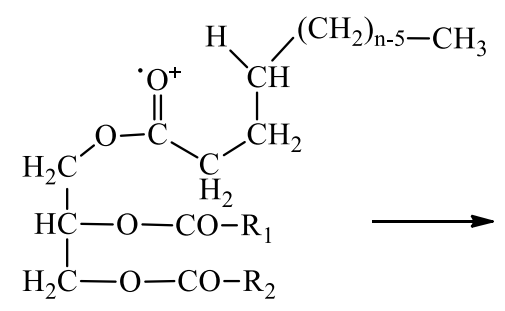

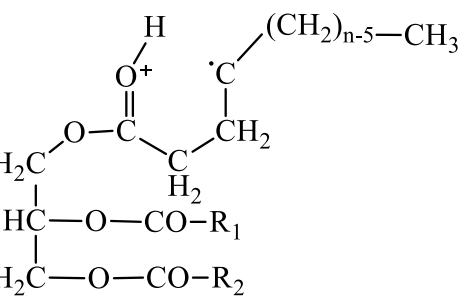

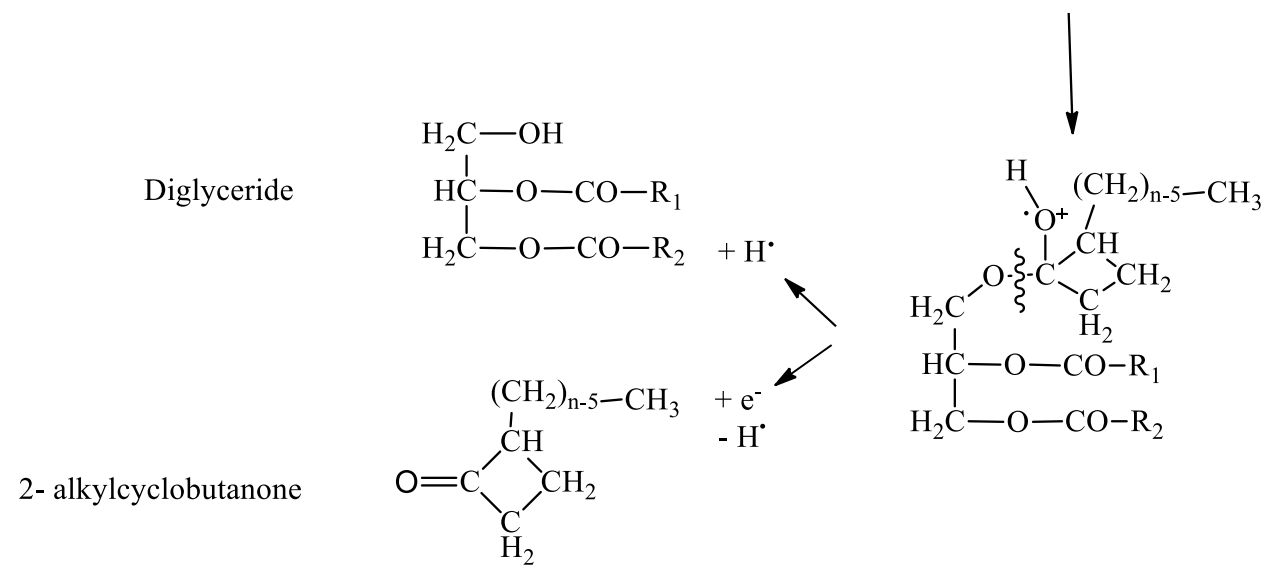

Source: Le Tellier and Nawar, 1972.

The 2-ACBs from irradiated food are usually present in trace amounts (in the range of parts per million). For example, the amount of 2-dDCB derived from palmitic acid, was estimated to be 12.9 $\mu \mathrm{g}$ per $100 \mathrm{~g}$ of chicken meat irradiated at $3 \mathrm{kGy}$ (Yamakage et al., 2014).

The main concern regarding the consumption of irradiated foods is the promotion of cancer by 2-ACBs. For example, a study from Delincée and Pool-Zobel (1998) reported a genotoxic effect of 2-ACBs in primary human and rodent colon cells. However, full studies of the possible effects of 2ACBs on irradiated foods as well as their mechanism(s) of action on tumorigenesis are still needed to address public health concerns. In fact, an in-depth investigation on how the levels of 2-ACBs consumed by humans and animal models can impact the promotion of several types of cancers is extremely important before advising that irradiated foods may or may not promote cancer (Chinthalapally, 2003). 
A variety of short-term tests for toxicological studies have been used to evaluate the genotoxic and cytotoxic potential of food additives and chemicals formed by processing technologies (Tice et al., 2000).

The cytotoxicity tests aim to evaluate and screen the cellular viability using in vitro cell lines to observe cell growth, reproduction and morphological effects, after exposure to various compounds. Cytotoxic assays are the first-choice tests for toxicity evaluation since they are simple, rapid and highly sensitive (Li et al., 2015).

\subsection{Cell Viability and 2-ACBs}

Several authors have already addressed the cytotoxic effect of 2-ACBs in colon cells using several different techniques. The cellular viability was evaluated varying the type of compound, concentrations and incubation times. TAB. 2 compiles all the in vitro cytotoxic studies using the 2ACBs compounds performed so far. Moreover, it shows that human colon cells such as, HT-29 (derived from human colon carcinoma), HT-29 Clone A (differentiated tumor line derived from HT29), LT-97 adenoma cells with preneoplastic characteristics) and mouse colon cells (not mentioned lineage), were mostly used in these studies. Taking into account that 2-ACBs can be deposited in adipose tissues, the use of colon cells can be explained because these cells contact directly with fat and is usually affected by its accumulation.

Table 2 - Authors and year in which the research was performed, compounds used, test of choice, cell line, evaluated concentration, incubation period and $\%$ of cell viability. The values referring to the $\%$ of viability are approximate data, since they represent reading of graphic curves where the points were not expressed exactly. 


\begin{tabular}{|c|c|c|c|c|c|c|c|c|c|}
\hline \multirow{2}{*}{ Author/ Year } & \multirow{2}{*}{ Compound } & \multirow{2}{*}{ Test } & \multirow{2}{*}{ Cell Line } & \multirow{2}{*}{ Concentration } & \multicolumn{5}{|c|}{ Period / \% Viability } \\
\hline & & & & & $30 \mathrm{~min}$ & $60 \mathrm{~min}$ & $90 \min 120 \mathrm{~min}$ & $24 \mathrm{~h}$ & $48 \mathrm{~h}$ \\
\hline \multirow{10}{*}{$\begin{array}{c}\text { Delincée at } \\
\text { al / } 1998\end{array}$} & 2-DCB & Tripan & Rat Cells & $0,25 \mathrm{mg} / \mathrm{ml}(1049 \mu \mathrm{M})$ & $85 \%$ & & & & \\
\hline & & Blue & & $0,50 \mathrm{mg} / \mathrm{ml}(2097 \mu \mathrm{M})$ & $65 \%$ & & & & \\
\hline & & & & $0,75 \mathrm{mg} / \mathrm{ml}(3146 \mu \mathrm{M})$ & $60 \%$ & & & & \\
\hline & & & & $1,00 \mathrm{mg} / \mathrm{ml}(4194 \mu \mathrm{M})$ & $57 \%$ & & & & \\
\hline & & & & $1,25 \mathrm{mg} / \mathrm{ml}(5243 \mu \mathrm{M})$ & $55 \%$ & & & & \\
\hline & & Tripan & Human & $0,25 \mathrm{mg} / \mathrm{ml}(1049 \mu \mathrm{M})$ & $55 \%$ & & & & \\
\hline & & Blue & cells & $0,50 \mathrm{mg} / \mathrm{ml}(2097 \mu \mathrm{M})$ & $48 \%$ & & & & \\
\hline & & & & $0,75 \mathrm{mg} / \mathrm{ml}(3146 \mu \mathrm{M})$ & $45 \%$ & & & & \\
\hline & & & & $1,00 \mathrm{mg} / \mathrm{ml}(4194 \mu \mathrm{M})$ & $40 \%$ & & & & \\
\hline & & & & $1,25 \mathrm{mg} / \mathrm{ml}(5243 \mu \mathrm{M})$ & $35 \%$ & & & & \\
\hline \multirow{45}{*}{$\begin{array}{l}\text { Delincée et } \\
\text { al / } 2002\end{array}$} & 2-tDCB & MTT & HT29 & $100 \mu \mathrm{mol}$ & $90 \%$ & & & $80 \%$ & $60 \%$ \\
\hline & & & & $200 \mu \mathrm{mol}$ & $\mathrm{N} / \mathrm{O}$ & & & $45 \%$ & $17 \%$ \\
\hline & & & & $400 \mu \mathrm{mol}$ & $\mathrm{N} / \mathrm{O}$ & & & $5 \%$ & $0 \%$ \\
\hline & 2-tDeCB & MTT & HT29 & $100 \mu \mathrm{mol}$ & $90 \%$ & & & $15 \%$ & $10 \%$ \\
\hline & & & & $200 \mu \mathrm{mol}$ & $90 \%$ & & & $10 \%$ & $0 \%$ \\
\hline & & & & $400 \mu \mathrm{mol}$ & $85 \%$ & & & $0 \%$ & $0 \%$ \\
\hline & 2-tDeCB & MTT & HT29 & $100 \mu \mathrm{mol}$ & $<=100 \%$ & & & $65 \%$ & $25 \%$ \\
\hline & cis-pure & & & $200 \mu \mathrm{mol}$ & $<=100 \%$ & & & $15 \%$ & $0 \%$ \\
\hline & & & & $400 \mu \mathrm{mol}$ & $100 \%$ & & & $5 \%$ & $0 \%$ \\
\hline & 2-dDCB & MTT & HT29 & $100 \mu \mathrm{mol}$ & $<=100 \%$ & & & $70 \%$ & $20 \%$ \\
\hline & & & & $200 \mu \mathrm{mol}$ & $<=100 \%$ & & & $5 \%$ & $0 \%$ \\
\hline & & & & $400 \mu \mathrm{mol}$ & $100 \%$ & & & $0 \%$ & $0 \%$ \\
\hline & 2-tDeCB & MTT & HT29 & $100 \mu \mathrm{mol}$ & $95 \%$ & & & $65 \%$ & $40 \%$ \\
\hline & trans-pure & & & $200 \mu \mathrm{mol}$ & $95 \%$ & & & $15 \%$ & $5 \%$ \\
\hline & & & & $400 \mu \mathrm{mol}$ & $95 \%$ & & & $5 \%$ & $0 \%$ \\
\hline & 2-tDCB & MTT & НТ29 & $100 \mu \mathrm{mol}$ & $<=100 \%$ & & & $75 \%$ & $50 \%$ \\
\hline & & & clone $19 \mathrm{~A}$ & $200 \mu \mathrm{mol}$ & $<=100 \%$ & & & $45 \%$ & $15 \%$ \\
\hline & & & & $400 \mu \mathrm{mol}$ & $<=100 \%$ & & & $10 \%$ & $5 \%$ \\
\hline & 2-tDeCB & MTT & HT29 & $100 \mu \mathrm{mol}$ & $<=100 \%$ & & & $75 \%$ & $57 \%$ \\
\hline & & & clone $19 \mathrm{~A}$ & $200 \mu \mathrm{mol}$ & $<=100 \%$ & & & $30 \%$ & $5 \%$ \\
\hline & & & & $400 \mu \mathrm{mol}$ & $90 \%$ & & & $10 \%$ & $5 \%$ \\
\hline & 2-tDeCB & MTT & HT29 & $100 \mu \mathrm{mol}$ & $<=100 \%$ & & & $55 \%$ & $55 \%$ \\
\hline & cis-pure & & clone $19 \mathrm{~A}$ & $200 \mu \mathrm{mol}$ & $<=100 \%$ & & & $30 \%$ & $5 \%$ \\
\hline & & & & $400 \mu \mathrm{mol}$ & $85 \%$ & & & $5 \%$ & $0 \%$ \\
\hline & 2-dDCB & MTT & НТ29 & $100 \mu \mathrm{mol}$ & $<=100 \%$ & & & $65 \%$ & $30 \%$ \\
\hline & & & clone $19 \mathrm{~A}$ & $200 \mu \mathrm{mol}$ & $100 \%$ & & & $25 \%$ & $0 \%$ \\
\hline & & & & $400 \mu \mathrm{mol}$ & $95 \%$ & & & $0 \%$ & $0 \%$ \\
\hline & 2-tDeCB & MTT & HТ29 & $100 \mu \mathrm{mol}$ & $<=100 \%$ & & & $55 \%$ & $40 \%$ \\
\hline & trans-pure & & clone $19 \mathrm{~A}$ & $200 \mu \mathrm{mol}$ & $<=100 \%$ & & & $25 \%$ & $5 \%$ \\
\hline & & & & $400 \mu \mathrm{mol}$ & $<=100 \%$ & & & $23 \%$ & $0 \%$ \\
\hline & 2-tDCB & WST & HT29 & $100 \mu \mathrm{mol}$ & $<=100 \%$ & & & $100 \%$ & $<=100 \%$ \\
\hline & & & & $200 \mu \mathrm{mol}$ & $<=100 \%$ & & & $100 \%$ & $<=100 \%$ \\
\hline & & & & $400 \mu \mathrm{mol}$ & $<=100 \%$ & & & $25 \%$ & $0 \%$ \\
\hline & 2-tDeCB & WST & HT29 & $100 \mu \mathrm{mol}$ & $95 \%$ & & & $<=100 \%$ & $<=100 \%$ \\
\hline & & & & $200 \mu \mathrm{mol}$ & $90 \%$ & & & $75 \%$ & $15 \%$ \\
\hline & & & & $400 \mu \mathrm{mol}$ & $95 \%$ & & & $20 \%$ & $0 \%$ \\
\hline & 2-tDeCB & WST & HT29 & $100 \mu \mathrm{mol}$ & $<=100 \%$ & & & $<=100 \%$ & $100 \%$ \\
\hline & cis-pure & & & $200 \mu \mathrm{mol}$ & $<=100 \%$ & & & $<=100 \%$ & $35 \%$ \\
\hline & & & & $400 \mu \mathrm{mol}$ & $<=100 \%$ & & & $50 \%$ & $5 \%$ \\
\hline & 2-dDCB & WST & HT29 & $100 \mu \mathrm{mol}$ & $100 \%$ & & & $100 \%$ & $<=100 \%$ \\
\hline & & & & $200 \mu \mathrm{mol}$ & $<=100 \%$ & & & $95 \%$ & $<=100 \%$ \\
\hline & & & & $400 \mu \mathrm{mol}$ & $<=100 \%$ & & & $25 \%$ & $0 \%$ \\
\hline & 2-tDeCB & WST & НT29 & $100 \mu \mathrm{mol}$ & $<=100 \%$ & & & $<=100 \%$ & $<=100 \%$ \\
\hline & trans-pure & & & $200 \mu \mathrm{mol}$ & $<=100 \%$ & & & $95 \%$ & $95 \%$ \\
\hline & & & & $400 \mu \mathrm{mol}$ & $<=100 \%$ & & & $45 \%$ & $0 \%$ \\
\hline
\end{tabular}




\begin{tabular}{|c|c|c|c|c|c|c|c|c|c|c|}
\hline \multirow{2}{*}{ Author/ Year } & \multirow{2}{*}{ Compound } & \multirow{2}{*}{ Test } & \multirow{2}{*}{ Cell Line } & \multirow{2}{*}{ Concentration } & \multicolumn{6}{|c|}{ Period / \% Viability } \\
\hline & & & & & $30 \mathrm{~min}$ & $60 \mathrm{~min}$ & $90 \mathrm{~min}$ & $120 \mathrm{~min}$ & $24 h$ & $48 h$ \\
\hline \multirow{15}{*}{$\begin{array}{c}\text { Delincée et } \\
\text { al / } 2002\end{array}$} & 2-tDCB & WST & HT29 & $100 \mu \mathrm{mol}$ & $98 \%$ & & & & $<=100 \%$ & $<=100 \%$ \\
\hline & & & clone $19 \mathrm{~A}$ & $200 \mu \mathrm{mol}$ & $100 \%$ & & & & $<=100 \%$ & $<=100 \%$ \\
\hline & & & & $400 \mu \mathrm{mol}$ & $<=100 \%$ & & & & $<=100 \%$ & $80 \%$ \\
\hline & 2-tDeCB & WST & НT29 & $100 \mu \mathrm{mol}$ & $<=100 \%$ & & & & $100 \%$ & $<=100 \%$ \\
\hline & & & clone $19 \mathrm{~A}$ & $200 \mu \mathrm{mol}$ & $<=100 \%$ & & & & $<=100 \%$ & $<=100 \%$ \\
\hline & & & & $400 \mu \mathrm{mol}$ & $<=100 \%$ & & & & $85 \%$ & $0 \%$ \\
\hline & 2-tDeCB & WST & HT29 & $100 \mu \mathrm{mol}$ & $95 \%$ & & & & $<=100 \%$ & $<=100 \%$ \\
\hline & cis-pure & & clone $19 \mathrm{~A}$ & $200 \mu \mathrm{mol}$ & $<=100 \%$ & & & & $<=100 \%$ & $<=100 \%$ \\
\hline & & & & $400 \mu \mathrm{mol}$ & $<=100 \%$ & & & & $<=100 \%$ & $5 \%$ \\
\hline & 2-dDCB & WST & НТ29 & $100 \mu \mathrm{mol}$ & $100 \%$ & & & & $90 \%$ & $<=100 \%$ \\
\hline & & & clone $19 \mathrm{~A}$ & $200 \mu \mathrm{mol}$ & $<=100 \%$ & & & & $<=100 \%$ & $<=100 \%$ \\
\hline & & & & $400 \mu \mathrm{mol}$ & $<=100 \%$ & & & & $<=100 \%$ & $0 \%$ \\
\hline & 2-tDeCB & WST & НТ29 & $100 \mu \mathrm{mol}$ & $80 \%$ & & & & $<=100 \%$ & $<=100 \%$ \\
\hline & trans-pure & & clone $19 \mathrm{~A}$ & $200 \mu \mathrm{mol}$ & $90 \%$ & & & & $<=100 \%$ & $<=100 \%$ \\
\hline & & & & $400 \mu \mathrm{mol}$ & $98 \%$ & & & & $<=100 \%$ & $45 \%$ \\
\hline \multirow{6}{*}{$\begin{array}{c}\text { Delincée at } \\
\text { al / } 2002\end{array}$} & 2-TCB & MTT & HT29 & $100 \mu \mathrm{mol}$ & $<=100 \%$ & & & & $80 \%$ & $60 \%$ \\
\hline & & & & $200 \mu \mathrm{mol}$ & $<=100 \%$ & & & & $40 \%$ & $20 \%$ \\
\hline & & & & $400 \mu \mathrm{mol}$ & $<=100 \%$ & & & & $10 \%$ & $0 \%$ \\
\hline & & MTT & НТ29 & $100 \mu \mathrm{mol}$ & $<=100 \%$ & & & & $78 \%$ & $50 \%$ \\
\hline & & & clone $19 \mathrm{~A}$ & $200 \mu \mathrm{mol}$ & $<=100 \%$ & & & & $45 \%$ & $18 \%$ \\
\hline & & & & $400 \mu \mathrm{mol}$ & $<=100 \%$ & & & & $10 \%$ & $3 \%$ \\
\hline \multirow{15}{*}{$\begin{array}{c}\text { Knoll at al / } \\
2006\end{array}$} & 2-dDCB & Tripan & HT29 & $150 \mu \mathrm{mol}$ & $94 \%$ & $89 \%$ & $92 \%$ & $82 \%$ & & \\
\hline & & Blue & clone $19 \mathrm{~A}$ & $300 \mu \mathrm{mol}$ & $94 \%$ & $88 \%$ & $89 \%$ & $88 \%$ & & \\
\hline & & & & $600 \mu \mathrm{mol}$ & $90 \%$ & $87 \%$ & $87 \%$ & $85 \%$ & & \\
\hline & & & & $1049 \mu \mathrm{mol}$ & $91 \%$ & $88 \%$ & $78 \%$ & $85 \%$ & & \\
\hline & & & & $2097 \mu \mathrm{mol}$ & $88 \%$ & $88 \%$ & $79 \%$ & $80 \%$ & & \\
\hline & 2-dDCB & Tripan & LT 97 & $150 \mu \mathrm{mol}$ & $89 \%$ & $74 \%$ & $62 \%$ & $19 \%$ & & \\
\hline & & Blue & & $300 \mu \mathrm{mol}$ & $87 \%$ & $72 \%$ & $38 \%$ & $10 \%$ & & \\
\hline & & & & $600 \mu \mathrm{mol}$ & $82 \%$ & $69 \%$ & $44 \%$ & $24 \%$ & & \\
\hline & & & & $1049 \mu \mathrm{mol}$ & $80 \%$ & $66 \%$ & $34 \%$ & $17 \%$ & & \\
\hline & & & & $2097 \mu \mathrm{mol}$ & $85 \%$ & $64 \%$ & $34 \%$ & $8 \%$ & & \\
\hline & 2-dDCB & Tripan & Primary & $150 \mu \mathrm{mol}$ & $77 \%$ & $65 \%$ & $34 \%$ & $18 \%$ & & \\
\hline & & Blue & Human & $300 \mu \mathrm{mol}$ & $67 \%$ & $52 \%$ & $27 \%$ & $11 \%$ & & \\
\hline & & & Colon & $600 \mu \mathrm{mol}$ & $70 \%$ & $48 \%$ & $19 \%$ & $11 \%$ & & \\
\hline & & & & $1049 \mu \mathrm{mol}$ & $59 \%$ & $45 \%$ & $25 \%$ & $9 \%$ & & \\
\hline & & & & $2097 \mu \mathrm{mol}$ & $67 \%$ & $43 \%$ & $14 \%$ & $8 \%$ & & \\
\hline \multirow{4}{*}{$\begin{array}{c}\text { Hartwig at al } \\
\text { / 2007 }\end{array}$} & 2-dDCB & Tripan & HT29 & $100 \mu \mathrm{mol}$ & $<=100 \%$ & & & & $65 \%$ & $35 \%$ \\
\hline & & Blue & clone $19 \mathrm{~A}$ & $200 \mu \mathrm{mol}$ & $<=100 \%$ & & & & $30 \%$ & $0 \%$ \\
\hline & & & & $300 \mu \mathrm{mol}$ & $<=100 \%$ & & & & $18 \%$ & $0 \%$ \\
\hline & & & & $400 \mu \mathrm{mol}$ & $<=100 \%$ & & & & $0 \%$ & $0 \%$ \\
\hline
\end{tabular}

In this study, concerning cytotoxic studies of the 2-ACBs already performed, we verified that its effect on human colon cells (HT 29, HT 29 clone 19A, LT97 primary cells) and mouse colon cells 
had been evaluated under doses as high as $2097 \mu \mathrm{M}$. This concentration is at a very high level, far above what is supposed to be consumed by humans in various periods, ranging from 30 minutes to 48 hours. The evaluation of the viability effect was performed through 3 cell viability assays (MTT, WST and Trypan Blue).

\section{MATERIAL AND METHODS}

\subsection{Test Substance - Compounds 2-ACBs and Solutions}

The chemical purity of 2-dDCB was $99.2 \%$ and 2-tDCB, $99.1 \%$ both were synthesized by Fluka Analytical and purchased from Sigma - Aldrich (EUA), CAS 35493-46-0 and CAS 35493-47-1.

\subsection{Cell Lines}

We used cells from hepatic lines of the BCRJ (Cell Bank of Rio de Janeiro). HepG2 (human hepatoma), BRL3A (normal hepatic cell) and HTC (rat hepatoma), available at ICB / USP (Institute of Biomedical Sciences of the University of São Paulo) in Cell and Tissue Biology and Development facilty, for use in micronucleus and cell viability tests.

- Defrosting cells

After removing the cryogenic tubes containing cells in liquid nitrogen they were thawed and their contents transferred to conical tubes containing culture medium (248 ml MilliQ water, $0.3 \mathrm{~g}$ sodium bicarbonate $\left(\mathrm{NaHCO}_{3}\right)$ and $3.9 \mathrm{~g}$ of DMEM (Dulbecco's Modified Eagle Medium) supplemented with $10 \%$ fetal bovine serum (FBS-Cultilab, São Paulo, Brazil) and then taken for centrifugation for 5 minutes at 1500 RPM, after which the supernatant contents of the tube were discarded, and the pellet formed was resuspended in $1 \mathrm{ml}$ of medium and then transferred to cell culture bottles containing $4 \mathrm{ml}$ of fresh culture medium, after which the bottles were conditioned in the oven under $5 \% \mathrm{CO} 2$ at $37^{\circ} \mathrm{C}$. 
- Cell Peal and Maintenance

After reaching near confluence, the peal / subculture of these cells was done. The medium was removed from the bottles and then washed with $3 \mathrm{ml}$ of PBS [deionized water, $0.2 \mathrm{~g}$ of potassium chloride $(\mathrm{KCl}), 0.2 \mathrm{~g}$ of potassium monobasic phosphate $\left.\mathrm{KH}_{2} \mathrm{PO}_{4}\right), 0.8 \mathrm{~g}$ of sodium chloride $(\mathrm{NaCl})$ and $1.15 \mathrm{~g}$ of anhydrous sodium phosphate $\left.\left(\mathrm{NaHPO}_{4}\right)\right]$, after the washing procedure, $1 \mathrm{ml}$ of trypsin (0.2\% Trypsin in PBS, + EDTA (0.02\%) solution) was added, and after complete cell detachment 1 $\mathrm{ml}$ of culture medium was added to inactivate the trypsin activity. New bottles were previously prepared with $5 \mathrm{ml}$ of culture medium already supplemented and then the cell suspension was aliquoted, usually among 2 or 4 bottles. This procedure was performed with all 3 cell lines and only after the third passage that they were used in the experiments.

\section{- Positive Control}

A latex solution was prepared to be used as a positive control. The extract was made from $0.1 \mathrm{~g} /$ $\mathrm{mL}$ latex $(0.5 \mathrm{~g}$ in $5 \mathrm{~mL})$ incubated at $37^{\circ} \mathrm{C}$ overnight. After this procedure, the extract was filtered with a $0.22 \mu \mathrm{m}$ membrane prior to use

\subsection{Evaluation of Cytotoxicity}

The evaluation of the cytotoxicity test was performed according to the protocol performed by Delincée et al., 2002, with some modifications such as the positive and negative controls used.

After resuspension of the cells in culture medium containing $10 \%$ FBS, they were then distribut-

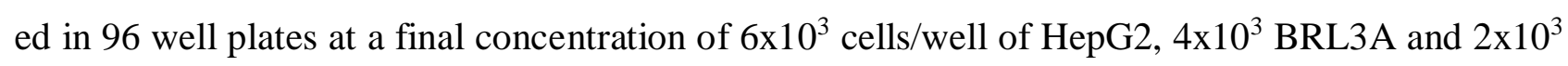
HTC, performed in quadruplicates. The final volume for distribution in the wells of the plates was $1.5 \mathrm{~mL}$, respectively. After 24 hours of incubation, the media were withdrawn from the wells and then the culture medium was added to the wells with the diluted compounds at the concentrations of $100 \mu \mathrm{M}, 300 \mu \mathrm{M}$ and $500 \mu \mathrm{M}$. In the positive control latex $(0,1 \mathrm{~g} / \mathrm{mL})$ was added, and in the negative control culture medium was added.

Exactly 4 hours before the end of each compound incubation period ( 24 and 48 hours) plates were removed from the stove (without aspirating the well contents) and added to each well 
CellTiter 96 Aqueous Non-radioactive Cell Proliferation Assay MTS (Promega Corporation G5421) previously prepared as reported by the manufacturer and then the first reading was performed on an EON Microplate Spectrophotometer microplate reader.

After reading the values of cell viability, data were evaluated through the GraphPad Prism program, analyzed and compared using ANOVA. Each experiment was repeated 3 times in non consecutive days.

\section{RESULTS}

According to ISO 10993, in 5 studies published in 2009, if a compound causes the reduction of cell viability by more than $30 \%$, it is considered to exert a cytotoxic effect. In this study, the cytotoxic effects of the 2-dDCB and 2-tDCB at concentrations of 100, 300 and $500 \mu \mathrm{M}$ were evaluated by MTS in BRL3A, HepG2 and HTC cell lines after 24 and 48 hours of exposure. As shown in Figure 2, 2-dDCB was found to be significantly toxic in BRL3A cells (at $100 \mu \mathrm{M}$ after 48 hours) and HTC cells (at 24 hours in all tested concentrations). HepG2 cells on the other hand, were found to be resistant to 2-dDCB-induced toxicity. For 2-tDCB, no toxicity was observed in all tested conditions for all cell lines. 
Figure 2 : Determination of the cytotoxic effects of 2-dDCB and 2-tDCB in different hepatic cell lines. In the BRL3A line we can observe a cytotoxic effect only in the concentration of $100 \mu \mathrm{M}$ in 2$d D C B$ for 48 hours period $(B)(* *): p<0.01$. HepG2 cell line showed no cytotoxicity at any concentration of 2-ACBs in any period evaluated $(C ; D)$. In the HTC cell line, the compound 2-dDCB showed cytotoxic effects in the 3 concentrations evaluated in 24 hours $(E)$ (****): $p<0.0001$ : $(* * *): p<0.001:(*): p<0.05$. However, in the 48-hour period no damage was observed in the concentrations of both compounds studied. Negative controls were Control Cells $(C C)$, Sodium chloride ( $\mathrm{NaCl}$. Positive Control of cytotoxicity: Latex.

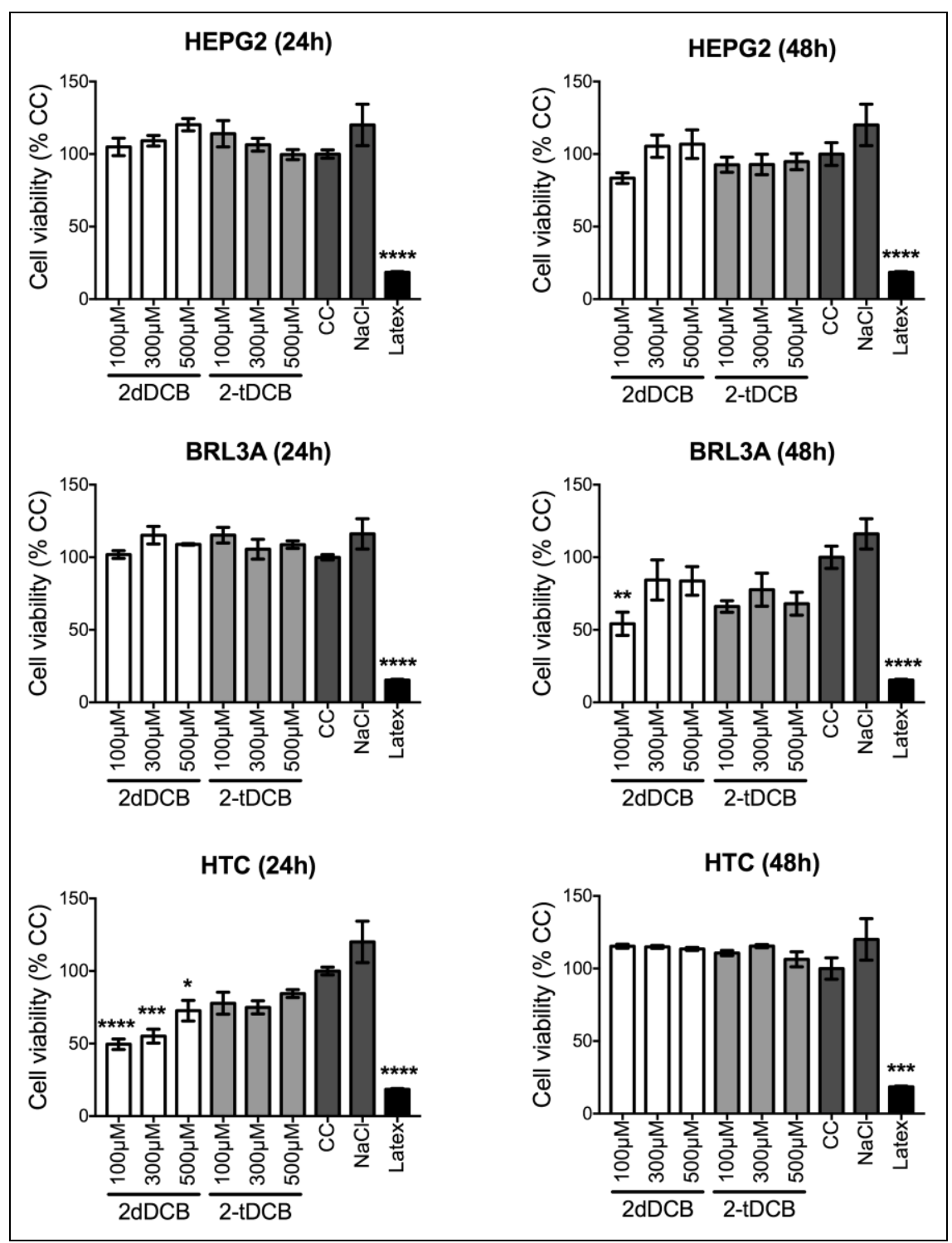




\section{DISCUSSION AND CONCLUSION}

In this study, a bibliographic survey was realized in order to study the cytotoxicity of 2-ACBs in different types of colon cells.

With the results and conclusions established, we decided to evaluate its effects in liver, considering that it is an organ that may accumulate fat, processes toxic compounds and is also involved in the digestive process. Hence, we choose liver cells (HepG2, HTC and BRL3A) to perform this study, in 3 different concentrations $(100,300$ and $500 \mu \mathrm{M}$, taking into consideration that a concentration of $500 \mu \mathrm{M}$ is extremely high compared to what is consumed by human being), in 2 periods (24 and 48 hours). Evaluation of viability effect was performed by the cell viability assay using the MTS dye reduction method.

In the literature, the research conducted by Delinceé and Pool Zobel (1998) analyzed the cytotoxicity of 2-DCB in colon cells of rats and humans obtained through biopsies and observed that cytotoxicity occurred with increasing concentrations. At $1.25 \mathrm{mg} / \mathrm{ml}(5.243 \mathrm{~m} / \mathrm{M}$ or $5243 \mu \mathrm{M})$ there was a reduction in the percentage of viable cells. They realized that the greatest observed effect occurred in human colon cells indicating to be more sensitive than rat cells. Viability was reduced to less than $50 \%$ at higher concentrations of $2-\mathrm{DCB}$, clearly showing that induced effects is dose dependent. Even with this important information, the test time was only 30 minutes, which is not the most adequate period. In 2002, Delinceé and colleagues continued to investigate the possible effects of 2-ACBs, now extending the period to 24 and 48 hours in the human colon tumor cell lines HT29 and HT29 clone 19A ${ }^{1}$ to evaluate the possible cytotoxic effect of compound 2-TCB. They found that, after prolonged action (1-2 days) and at higher concentrations, cytotoxic damages were observed; however, they pointed out that these damages only appeared at very high concentrations, when compared with human intake. Based on the data from the previous tests, Delincée and his team (2002a) decided to extend the scope of the tests, varying the compounds of the 2-ACBs family (2-tDeCB / 2-(tetradec'-enyl)-cyclobutanone, 2- $\mathrm{dDCB}$ in the same cell lines used in the previous

\footnotetext{
${ }^{1}$ According to Delincée et al. (2002) Tumor cells from the human colon HT29 were obtained from a primary tumor of an adenocarcinoma. An HT $29 \mathrm{cl}$ 19A clone was obtained after treatment of HT 29 cells by sodium butyrate (Augeron and Laboisse, 1984). Undifferentiated HT 29 cells developed new properties, such as increased adhesion to the bottom of the vials and the possibility of forming "flat hearths". HT 29 cells, available in the differentiated or undifferentiated step, can now be tested for sensitivity to toxic compounds at various stages of their development.
} 
test - HT29 and HT29 clone 19A), the type of test (MTT and WST), maintained the incubation time (24 and 48 hours) and the concentrations (100, 200 and $400 \mu \mathrm{M})$. No cytotoxic damage was observed within 30 minutes after incubation; however, at longer periods and concentrations $(\geq 100 \mu \mathrm{M})$, damages were observed.

Knoll et al. (2006) evaluated cytotoxicity of compound 2dDCB (150 to $2097 \mu \mathrm{M})$ in colon tumor human cells (HT29 clone 19A), adenoma cells (LT 97) and primary human colon cells. In that study, the primary cells were more sensitive to $2 \mathrm{dDCB}$. There were reduction of viability in 120 minutes of in vitro culture and additionally as far as concentration of $2 \mathrm{dDCB}$ was increased, showing a dose dependent effect. In LT 97 lines, effects were observerd after 60 minutes in $600 \mu \mathrm{M}$ concentration of $2 \mathrm{dDCB}$

They concluded that, in both cases, at the maximum concentrations tested, the compound could be defined as "subtoxic" and therefore suitable for genotoxic assessments.

Hartwing et al. (2007), applying the 2-dDCB compound to human colon tumor cells (HT 29 clone 19A) at concentrations between 100 and $400 \mu \mathrm{M}$, also observed no change within the 30 minute period, but in the same way as reported in other articles, cytotoxicity effects of the compound were seen as dose and time increased. The author reported that there were no significant differences observed in the viability of HT 29 and HT 29 clone 19A cells after incubation with 2dDCB using the MTT test (HT cell data 29 not shown in the paper).

After all the available literature, with the results and conclusions already established regarding the cytotoxic effects of 2-ACBs in colon cells, we can use it as a parameter and compare it to the study performed in the hepatic cells.

As per ISO 10993:5 standards (cytotoxic effect considered if cell viability drops to $~ 30 \%$ ), it was observed that in the BRL3A cell line, only the 2-dDCB compound at concentration of $100 \mu \mathrm{M}$ in 48 hours the period, has presented cytotoxic effect. However, at 300 and $500 \mu \mathrm{M}$ none effect was observed. A possible explanation for this result may be the hormesis effect, which suggests that the same substance that has a certain action at high concentrations acts inversely at high dilutions (Calabrese, 2008). But we can not say that this is really the reason for our results. For this statement would be necessary other studies focusing on the possible hormesis effect. 
The cell line derived from human hepatoma (HepG2) showed no inviability in any of the evaluated parameters, differently from what the authors Delinceé and Zobel (1998) and Hartwing et al. (2007) found. They reported in their study with human colon tumor cell line that, when concentration of the compound was increased, damage increased as well, which suggested to be dose dependent. However in this experimental study, this dose dependence was not observed with human HepG2 line or with another type of lineage evaluated.

The HTC cell line showed cytotoxicity when exposed to compound 2-dDCB at the 3 concentrations studied after 24 hours. The same was not observed when cells were exposed to compound 2tDCB at the same time. Cytotoxic damages were not noticed within 48 hours when the lineage was treated with the two compounds compounds at all concentrations and periods investigated.

Regarding compound 2-tDCB, although in some cases the cell viability did not present $100 \%$, according to parameter ISO 10993:5, it was not cytotoxic in any of the evaluated situations.

As is known, the 2-ACBs ingested are part excreted through the feces and partly deposited in the adipose tissue. Until the accomplishment of this work had only been realized studies of the action of the 2-ACBs in colon cells, since this region is affected by the accumulation of fat.

However, there is another organ that is also usually affected by the accumulation of fat, the liver. In the last years it has presented pathological occurrences that would not be related to any genetic factor. So, this was the organ chosen to investigate whether 2-ACBs would have some cytotoxic effect and, consequently, some promoter effect on liver cancer.

Colon cells produce mucus, which changes the interaction with substances, beyond to be epithelial. In addition, they do not possess activity capable of metabolizing compounds, which makes the responses different from liver cells. There is an in vitro study with canine cells that has shown that certain lipids (essential oils) are more cytotoxic in enterocytes than in hepatocytes (MonteiroRiviere et al, 2015).

For this reason, the results presented here differ from the results found in the existing literature. This shows the novelty of this study, as there are no studies available in the literature regarding 2ACBs / liver cells.

After all these analyzes, observing each study, we can conclude that there is a cytotoxic effect of the 2-ACBs tested in colon cells. When concentrations and time were increased, their effects on sensitivity were also increasingly evident, showing to be totally dose - dependent, although the 
greatest effect was observed at relatively high doses when compared to actual human consumption. We did not visualize similarity between the analyses observed with colon cells from bibliographic survey to the experimental study performed with liver cells.

Further additional studies should be performed regarding the cytotoxic potential of 2-ACBs, increasing the concentrations and the periods evaluated as well as the cell type to be studied, especially when dealing with organs that have accumulation of fat and are involved in the digestive process, knowing that part of the 2-ACBs are excreted through the feces and partly remain deposited in adipose tissues, before categorically asserting that the alkylcyclobutanones provide or not a serious cytotoxic effect.

\section{REFERENCES}

[1] KIM, K. S.; S. E.O.; H. Y.; LEE, J. M.; PARK, E. R.; KIM, J. H.; HONG, C. H.; BYUN, M. W. Analysis of radiation-induced hydrocarbons and 2-alkylcyclobutanones from dried shrimps (Penaeus aztecus). J Food Prot. v. 67, p. 142-147, 2004.

[2] FARKAS, J.; EHLERMANN, D. A. E.; FARKAS, C. M. Food Technologies: Food Irradiation. Reference Module in Food Science - Enc. Food Safety. 3: 178-186, 2014.

[3] EHLERMANN, D. A. E. The early history of food irradiation. Radiat. Phy. Chem. 129: 10-12, 2016.

[4] LE TELLIER, P.; NAWAR, W. W. 2-Alkylcyclobutanones from radiolysis of triglycerides. Lipids, 7: 75-76, 1972.

[5] SONG, B. S. ; CHOI, S. J. ; JIN, Y. B. ; PARK, J. H. ; KIM, J. K. ; BYUN, E. B. ; KIM, H. ; MARCHIONI, E. "A critical review on toxicological safety of 2- alkylcyclobutanones". Radiat. Phy. and Chem. v. 103, pp. 188-193, 2014. 
[6] GADGIL, P.; HACHMEISTER, K.; SMITH, J. S.; KROPF, D. H. 2-Alkylcyclobutanones as Irradiation Dose Indicators in Irradiated Ground Beef Patties J. Agric. Food Chem, 50: 5746-5750, 2002.

[7] YAMAKAGE, K.; SUI, H.; OHTA, R.; TYOIZUMI, T.; KAWAKAMI, K.; MATSUMOTO, H.; TAKAHASHI, T.; SASAKI, K.; IKEZUMI, M.; NEGISHI, S.; IZUMI, K.; TODORIKI, S.; TAKASHI, K.; FURUTA, M. Genotoxic potencial and in vitro tumour-promoting potential of 2dodecylcyclobutanone and 2-tetradecylcyclobutanone, two radiolytic products of fatty acids. Mutat Res. 770: 94-104, 2014.

[8] DELINCEÉ, H.; POOL-ZOBEL, B.L. Genotoxic properties of 2-dodecylcylobutanone, a compound formed on irradiation of food containing fat. Radiat. Phy. Chem. 52: 39-42, 1998.

[9] CHINTHAlapally, V. R. Do Irradiated Foods Cause or Promote Colon Cancer? (2003) Division for cancer prevention, American health Foundation-Cancer.

[10] TICE, R. R.; E. AGERELL; D. ANDERSON; B. BURLISON; A. HARTMANN; H. KOBAYASHI; Y. MIYAMAE; E. ROJAS; J. C. RYU; Y. F. SASAKI. Single cell gel/comet assay: guidelines for in vitro and in vivo genetic toxicology testing. Environ. Mol. Mutagen. 35: 206-221, 2000.

[11] LI, W.; ZHOU, J.; XU,Y. Study of the in vitro cytotoxicity testing of medical devices (Review). Biomed Rep. 3: 617-620, 2015.

[12] ISO 10993-5 International Standard. Biological evaluation of medical devices - Part 5: Tests for in vitro Cytotoxicity. Third edition, 2009.

[13] DELINCEÉ, H.; SOIKA, C.; HORVATOVICH, P.; HODAPP, C.; RECHKEMMER, G. Cytotoxicité et génotoxicité des 2-akkylcyclobutanones vis à vis des lignées de cellulas tumorales humaines (HT 29 et HT 29 cl 19A). Bundesforschungsanstalt für Erährung 
Karlsruhe. 57-72, 2002.

[14] DELINCEÉ, H.; SOIKA, C.; HORVATOVICH, P.; RECHKEMMER, G.; MARCHIONI, E. Genotoxicity of 2 alkylcyclobutanones markers for an irradiation treatment in fat-containing food - Part I: Cyto - and genotoxic potential of 2-Tetradecylcyclobutanone. Radiat. Phy. Chem. 63: 431-435, 2002a.

[15] KNOLL, N., WEISE, A., CLAUSSEN, U., SENDT, W., MARIAN, B., GLEI, M., POOLZOBEL, B. L. 2-dodecylcyclobutanone, a radiolytic product of palmitic acid, is genotoxic in primary human colon cells and in cells from preneoplastic lesions. Mutat. Res. 594: 10-19, 2006.

[16] HARTWING, A., PELZER, A., BURNOUF, D., TITÉCA, H., DELINCÉE, H., BRIVIBA, K., SOIKA, C., HODAPP, C., RAUOL, F., MIESCH, M., WERNER, D., HORVATOVICH, P., MARCHIONI, E. Toxicological potential of 2-alkylcyclobutanones - specific radiolytic products in irradiated fat-containing food - in bacteria and human cell lines. Food Chem. Toxicol. 45: 25812591, 2007.

[17] CALABRESE, E.J., STANEK, E.J., NASCARELLA, M.A., HOFFMANN, G.R., "Hormesis Predicts Low-Dose Responses Better Than Threshold Models". Int J Toxicol. 27: 369-378, 2008.

[18] MONTEIRO-REVIERI, N.A., ORTEGA, M.T., CHOI, K., KOSI, J., LIN, Z., JEFFERY, B., REVIEIRI, J.E., “Comparative in vitro Cytotoxicity of 20 Potential Food Ingredients in Canine Liver, Kidney, Bone Marrow-Dereived Mesenchymal Stem Cells, and Enterocyte-like Cells". Appl In Vitro Toxicol. 1:4, 2015, 